(C)Carcinological Society of Japan. doi: 10.18353/crustacea.50.0_103

\title{
Observations in life of Eiconaxius baja Kensley, 1996 (Crustacea, Decapoda, Axiidea, Axiidae), a sponge commensal lobster
}

\author{
Mary K. Wicksten
}

\begin{abstract}
Three species of the sponge-dwelling lobster Eiconaxius are known from the eastern Pacific. Previous reports and descriptions were based on dead specimens. During a study by remotely operated vehicle, Eiconaxius baja was photographed in situ at the San Juan Seamount within a sponge of the family Phariidae. It tried to escape by swimming backward. Illuminated by the lights of the vehicle, the lobster had an orange color. The depth at which the lobster lives has no ambient light, so the function of the color remains uncertain.
\end{abstract}

Key words: lobster, Eiconaxius, commensal, sponge, Phariidae, northeastern Pacific

Members of the infraorder Axiidea Huxley, 1879, sometimes confusingly called "lobster shrimps", range from the intertidal zone to great depths. There are 34 species of Eiconaxius (family Axiidae), of which only three are known from the eastern Pacific (Kensley, 1996). Eiconaxius albatrossae Kensley, 1996, collected off Pacific Panama, and E. cristagalli (Faxon, 1893), off Pacific Panama and the Galapagos Islands, are known only from their type material. (See Poore, 2017 for a discussion of the nomenclature of E. albatrossae). Species of Eiconaxius are thought to be sponge commensals.

Eiconaxius baja Kensley, 1996 previously was known from the type material, 10 specimens taken off Guadalupe Island, Baja California, Mexico $\left(28^{\circ} 57^{\prime} 00^{\prime \prime} \mathrm{N} \quad 118^{\circ} 14^{\prime} 30^{\prime \prime} \mathrm{W}\right)$, $1252 \mathrm{~m}$, with sponge fragments, Albatross station 2986, USNM 2112495). Wicksten (1982, Fig. 1) reported two specimens of E. baja (as Axius acutifrons (Bate, 1888) recovered from hexactinellid sponges during trap studies south of Cortez Bank $\left(32^{\circ} 15^{\prime} \mathrm{N}, 119^{\circ} 36^{\prime} \mathrm{W}-30^{*} 00^{\prime} \mathrm{N}\right.$ $\left.119^{\circ} 39^{\prime} \mathrm{W}, 1850-2310 \mathrm{~m}\right)$ and south of San Clemente Island $\left(32^{\circ} 22.5^{\prime} \mathrm{N} 118^{\circ} 38.0^{\prime} \mathrm{W}, 1108 \mathrm{~m}\right)$. These specimens, deposited at the Natural History Museum of Los Angeles County (catalog number LACM:DISCO:20367) were re-examined and found to be E. baja. The upturned rostrum is characteristic.

On 30 October 2020, the exploratory vessel Nautilus deployed the remotely operated vehicle Hercules at the San Juan Seamount (33 $\left.04.2^{\prime} \mathrm{N}, 120^{\circ} 58.8^{\prime} \mathrm{W}\right)$. Hercules was equipped with high resolution video cameras and both claw and suction collecting gear. A single ovigerous female E. baja, carapace length $9.8 \mathrm{~mm}$, with 9 eggs, was photographed in a hexactinellid sponge (family Phariidae) and collected at $1077 \mathrm{~m}$ (Fig. 2) . This lobster was deposited in the Marine Invertebrate Collection of Scripps Institution of Oceanography, SIO catalog number SIO-BIC-C14467. A tissue sample is available for genetic analysis. Video of the lobster showed that it clambered quickly within the sponge. It tried to escape by flipping the abdomen and swimming backward.

The lights of the ROV illuminated the lobster. There was no ambient light at the depth of collection The color in life was orange, without pigment in the eyes (Fig. 1). Compared to other axiid lobsters living at depth, E. baja has a dark opaque color. Eiconaxius acutifrons Bate, 1888 and E. goldobovi Poore, 2019 are transparent white (Komai and Tsuchida 2012, Fig. 
WICKSTEN M. K.

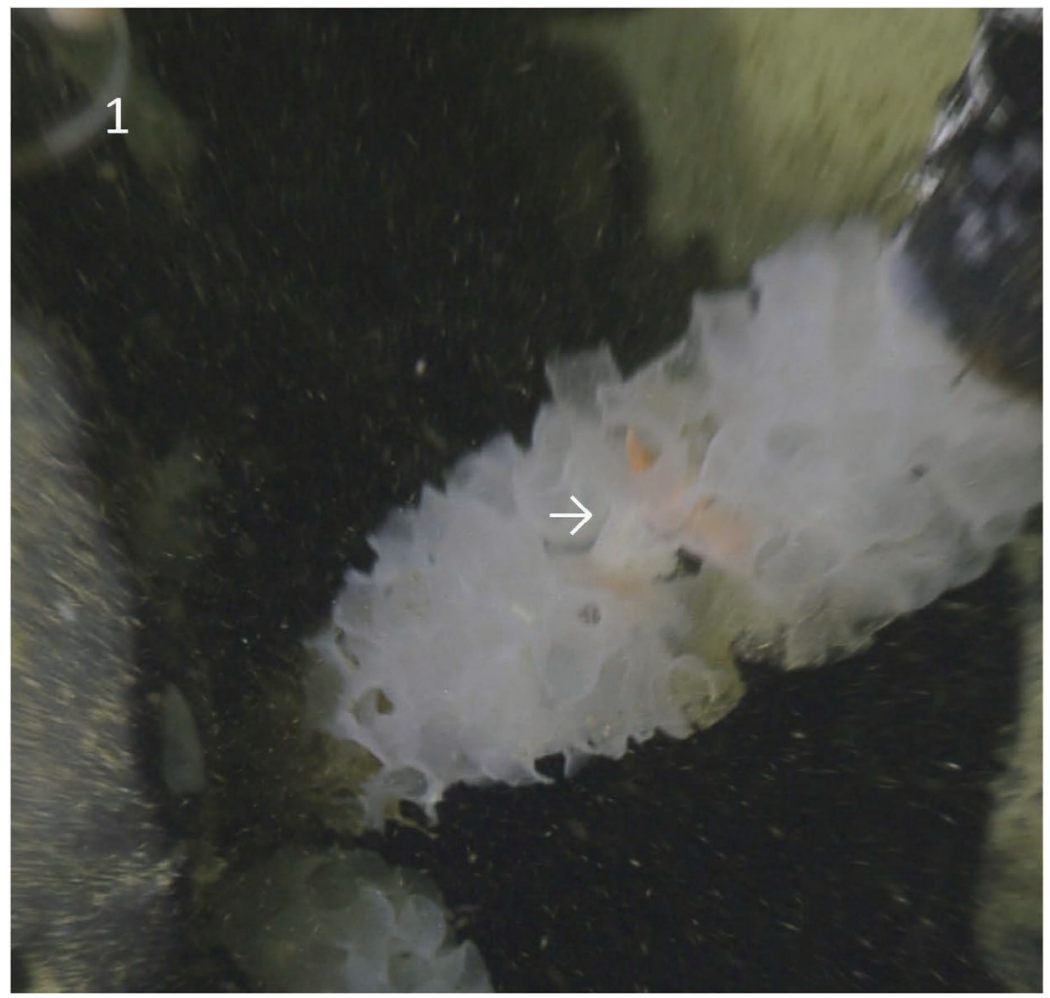

Fig. 1. Eiconaxius baja in sponge (Phariidae) at San Juan Seamount.

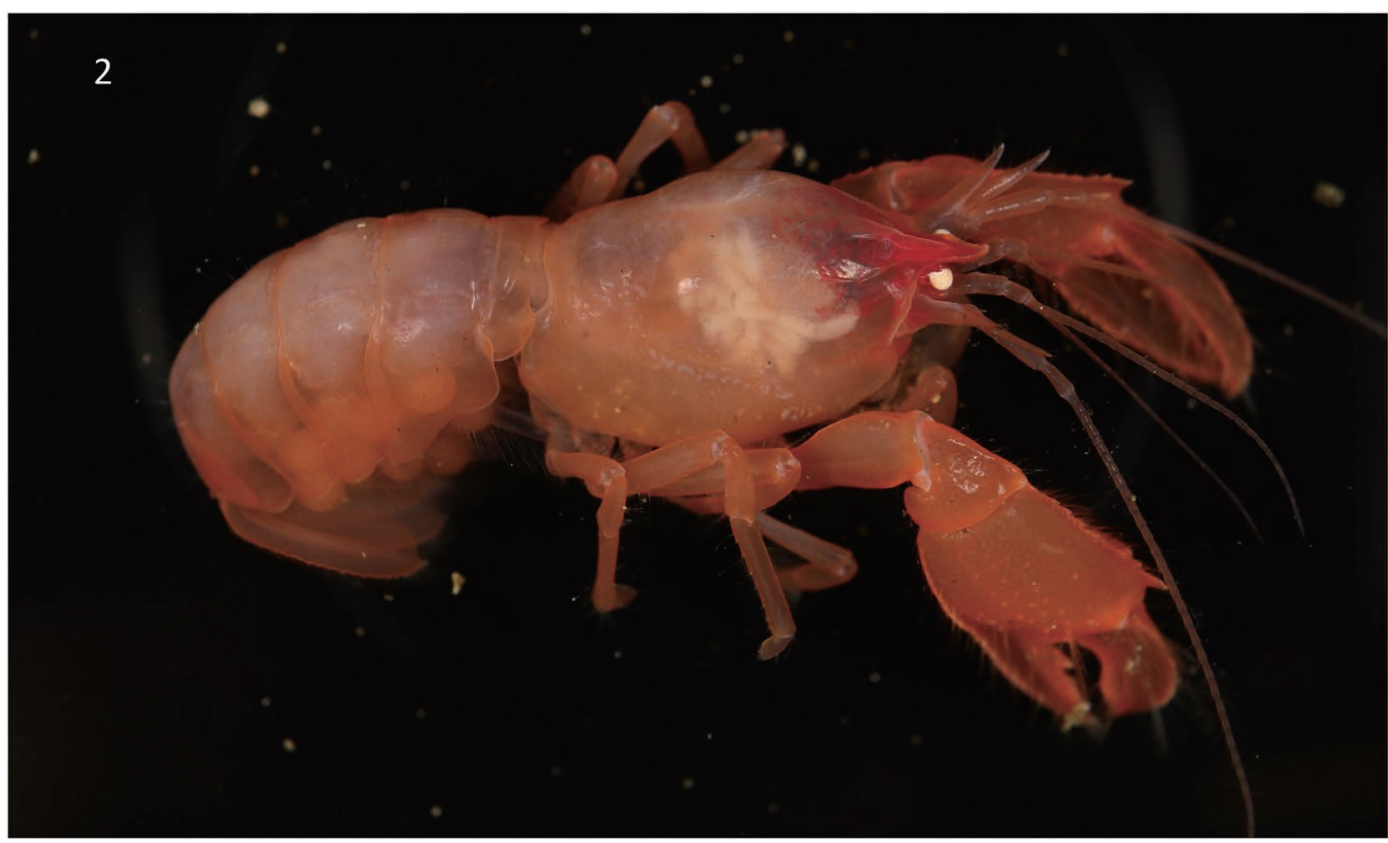

Fig. 2. Freshly collected specimen of Eiconaxius baja. 
6; Poore 2019, Fig. 4). Eiconaxius serratus Kuo, Xu, Poore, Li \& Wang, 2020, E. bunibudi Poore, 2020, E. sibogae (de Man, 1925) and E. dangshaiensis Poore, 2019 have pale orange to red marks, especially on the cephalothorax (Poore, 2019, Fig. 4; 2020, Fig. 12; Kou et al. 2020, Fig. 1.) Eiconaxius demani Sakai, 1912 shows some variation in color, one photographed individual having more red pigment on the anterior body than another (Poore, 2020, Fig. 12 B, C). The color would be unlikely to provide visual camouflage for a lobster living inside a sponge. The color could have been due to carotenoid pigments serving a physiological function, perhaps in strengthening the exoskeleton. Other benthic crustaceans at San Juan Seamount varied in color from dark red, as in the lithodid crab Paralomis multispina (Benedict, 1895) to dirty brown, as in the majoid crab Chorilia longipes Dana 1851, or white (unidentified Munidopsis sp.)

Hexactinellid sponges at San Juan Seamount and other offshore rocky habitats provide a habitat not only for axiids but also for ophiuroids as well as amphipods and caridean shrimps (family Thoridae, unidentified). A sponge can provide anchorage or hiding places. Further study is needed to determine if these associations are species-specific and what, if any, benefit accrues to the sponge.

\section{Acknowledgements}

The exploration of the E.V. Nautilus was funded by the Ocean Exploration Trust and the U.S. National Oceanographic and Atmospheric Administration (NOAA) Office of Ocean Exploration and Research. Many thanks are due to Lisa Levin and Charlotte Seid, Scripps Institution of Oceanography, University of California at San Diego for the loan of the specimen and Tom Laidig of NOAA for help with providing data. Adam Wall and Regina Wetzer, Natural History Museum of Los Angeles, located the specimens of E. baja in their collec- tions and checked the identification. Reviewer Gary C. B. Poore of Museums Victoria suggested additional helpful references.

\section{$\square$ Literature Cited}

Bate, C. S., 1888. Report on the Crustacea Macrura collected by the H.M.S. Challenger during the years 1873-76. Reports of the Voyage of the Challenger, Zoology, 4: $1-942$.

Benedict, J. E., 1895. Descriptions of new genera and species of crabs of the family Lithodidae with notes on the young of Lithodes camtschaticus and Lithodes brevipes. Proceedings of the United States National Museum, 17: 479-488.

Dana, J. D., 1851. Conspectus Crustaceorum quae in orbis terrarum circumnavigatione, Carolo Wilks e Classe Reipublicae Faederatae duce, lexit et descripsit. Pars VI. American Journal of Science, series 2, 11: 268274.

Faxon, W., 1895. Reports on an exploration off the west coast of Mexico, Central and South America, and off the Galapagos Islands, in charge of Alexander Agassiz, by the U.S. Fish Commission Steamer "Albatross" during 1891, Lieut.-Commander Z. Tanner, U.S.N., commanding. XV. The stalk-eyed Crustacea. Memoirs of the Museum of Comparative Zoology at Harvard College, 18: 1-292.

Huxley, T. H., 1879. On the classification and the distribution of the crayfishes. Proceedings of the Scientific meetings of the Zoological Society of London, 46: 752-788.

Kensley, B., 1996. New thalassinidean shrimp from the Pacific Ocean (Crustacea: Decapoda: Axiidae and Calocarididae). Bulletin of Marine Science, 59: 469-489.

Komai, T., \& Tsuchida, S. 2012. Rediscovery and redescription of a sponge-associated axiid shrimp, Eiconaxius acutifrons Bate, 1888 (Crustacea: Decapoda: Axiidea). Zootaxa, 3393: 27-40. 
Kou, Q., Xu, P., Poore, G. C. B., Li, X, \& Wang, C. 2020. A new species of the deep-sea sponge-associated genus Eiconaxius (Crustacea: Decapoda: Axiidae), with insights into the distribution, speciation, and mitogenomic phylogeny of axiidean shrimps. Frontiers in Marine Science 7(469): 1-26. https:// doi.org/10.3389/fmars.2020.00469.

Man, J. G. de. 1925. Axiopsis (Eiconaxius) sibogae n. sp. Zoologische Mededelingen Leiden, 8: 218-219.

Poore, G. C. B. 2017. Synonymy and problematic species of Eiconaxius Spence Bate, 1888 with descriptions of new species (Crustacea: Decapoda: Axiidea: Axiidae). Zootaxa 4231 (3): 364-376, DOI: 10.11646/zootaxa.4231.3.4.

Poore, G. C. B. 2020. Axiid and micheleid lobsters from Indo-West Pacific deep-sea environments (Crustacea: Decapoda: Axiidea: Axiidae, Micheleidae). In: Corbari, L., Chan, T.-Y., \& Ahyong, S. (eds). Papua New Guinea. Tropical Deep-Sea Benthos vol. 31. Mémoires du muséum National d'Histoire Naturelle, Paris, 213: 259-367.

Poore, G., C. B. \& Dworschak, P. 2018. The Eiconaxius cristagalli species complex (Decapoda, Axiidea, Axiidae). Memoirs of Mu- seum Victoria, 77: 105-120.

Sakai, K. 1992. Axiid collections at the Zoological Museum, Copenhagen, with the description of one new genus and six new species (Axiidae, Thalassinidea, Crustacea). Zoologica Scripta, 21: 157-180.

Sakai, K. \& Ohta, S. 2005. Some thalassinid collections by R/V "Hakuhou-Maru" and R/V "Tansei-Maru”, University of Tokyo, in the Sulu Sea, Philippines, and in Sagami Bay and Suruga Bay, Japan, including two new species one new genus, and one new family (Decapoda,Thalassinidea). Crustaceana, 78: 67-93.

Wicksten, M. K., 1982. Crustaceans from baited traps and gill nets off southern California. California Fish and Game, 68: 244-248.

\section{Address}

(MKW) Department of Biology, Texas A\&M University, College Station Texas 77843-3258 U.S.A.

\section{E-mail address}

m-wicksten@tamu.edu 